\title{
Yet another record of Charybdis hellerii (A. Milne Edwards) (Crustacea, Decapoda) from the Northeast of Brazil
}

\author{
Alexander C. Ferreira ${ }^{2}$ \\ Cheruparambil Sankarankuty ${ }^{1}$ \\ Inailson M.C. da Cunha ${ }^{3}$ \\ Fábio T. Duarte ${ }^{3}$
}

\begin{abstract}
The presence of Charybdis helleri (A. Milne Edwards, 1867), an Indo-Pacific species, in one of the estuaries of the State of Rio Grande do Norte, Brazil is reported here.

KEY WORDS. Crustacea, Decapoda, Charybdis helleri
\end{abstract}

Charybdis hellerii (A. Milne Edwards, 1867) (Crustacea, Decapoda), a species extensively distributed in the Indo-Pacific region and often fished as a commercial catch, has been extending its distribution into the Atlantic Ocean in recent years. Based on the publications available (GómEZ \& MARTÍNEZ-IGLESIAS 1990; Lemaitre 1995; TAVARES \& MendonÇA 1996; Mantelatto \& Dias 1999), it can now be confirmed that the species has established itself in the Western Atlantic region.

LEMAITRE (1995) and TAVARES \& MENDONÇA (1996), while reporting on the occurrence of the species in the Florida region and Brazilian coastal waters respectively, have attempted to trace the chronological sequence of the invasion of the species into the western Atlantic region. While the species has been known to occur in the Caribbean waters (GómEZ \& MARTíneZ-IGLESIAS 1990; CAMPOS \& TURKAY 1989) and Venezuela (GómEZ \& MARTínEZ-IGLESIAS 1990) from 1987, its presence along the Brazilian coastal waters has been confirmed only recently (CAlado 1996; CARqueija \& GouvÊA 1996; TAVARES \& MEndonÇA 1996 and Mantelatto \& Dias 1999). Lemaitre (1995) and Tavares \& MEndonça (1996) have attempted to explain the mechanism of introduction of this exotic species and are of the opinion that the species had its entry into the region facilitated through the movement of the ships. The species was known to have reached the Mediterranean region as early as 1978 (POR 1978) where it is considered to have established itself. The fact that NegreIros-Fransozo (1996) and TAVARES \& MENDONÇA (1996) have been able to collect ovigerous females from the São Paulo and Rio de Janeiro, Brazil, regions respectively, shows that the species can breed successfully in this region and hence can be added to its faunistic list.

1) Departamento de Oceanografia e Limnologia, Universidade Federal do Rio Grande do Norte. 59014-100 Natal, Rio Grande do Norte, Brazil. Research of the CNPq.

2) Fellow of the CNPq.

3) Fellow PIBIC/CNPq. 
During the recent survey of the decapod fauna of the sublittoral region in the estuaries of the Rio Grande do Norte State, Brazil initiated in 1997, three juvenile specimens of $C$. hellerii, a male measuring $13.5 \mathrm{~mm}$ (carapace width -c.w.) $/ 9.7 \mathrm{~mm}$ (carapace length -c.l.), and two females measuring $13 \mathrm{~mm}$ (c.w)/9.4 mm (c.l.) and $17.3 \mathrm{~mm}(\mathrm{c} .1.) / 12 \mathrm{~mm}$ (c.l.) from the estuary of Galinhos ( $\left.5^{\circ} 07^{\prime} \mathrm{S}, 36^{\circ} 15^{\prime} \mathrm{W}\right)$, and a recently moulted male of similar size from an estuary close to Macau $\left(05^{\circ} 06^{\prime} \mathrm{S}\right.$, $36^{\circ} 34^{\prime} \mathrm{W}$ ) were collected.

The present finding together with the earlier observations establishes a continuous distribution for the species along the western Atlantic region from Florida to São Paulo through the Caribbean region. It is, however, quite likely that the introduction of the Brazilian population must have taken place independent of that in the Caribbean as suggested by GómEZ \& MARTíNEZ-IGLESIAS (1990) taking into consideration the pattern of the flow of the Brazilian current - in which case the species might have been introduced initially in the northeast from where it has subsequently spread to the southern part of Brazil through larval transport.

\begin{abstract}
ACKNOWLEDGEMENTS. The authors are grateful to the CNPq for the award of a research scholarship during the tenure of which this work was carried out. The junior author (C.S.) is also grateful to the CAPES and the British Council for the financial support to visit The Natural History Museum, London. Thanks are also due to Dr. Paul Clark for the hospitality extended (C.S.) during his visit to the Natural History Museum.
\end{abstract}

\title{
REFERENCES
}

CALAdO, T.C.S. 1996. Registro de Charybdis hellerii (Milne Edwards, 1867) em aguas de litoral brasileiro (Decapoda: Portunidae). Bol. Estud. Ciênc. Mar., Maceió, 9: 175-180.

CAMPOS, N.H. \& M. TURKAY. 1989. On a record of Charybdis helleri from the Caribbean coast of Colombia. Senckenb. Marit. 20 (3/4): 119-123.

CARQueIJA, C.R.G. \& E.P. GouvÊA. 1996. A ocorrência, na costa brasileira, de um Portunidae (Crustacea, Decapoda). originário do Indo-Pacífico e Mediterrâneo. Nauplius, Rio Grande, 4: 165-168.

Gomez, O. \& J.C. MARTinez-IgLESIAS. 1990. Reciente hallazgo de la especie indopacífica Charybdis hellerii (A. Milne Edwards, 1867) (Crustacea: Decapoda: Portunidae) en aguas cubanas. Caribb. Jour. Sci. 26 (1-2): 70-72.

LEMAITRE, R. 1995. Charybdis hellerii (Milne Edwards, 1867), a non-indigenous portunid crab (Crustacea: Decapoda: Brachyura) discovered in the Indian River lagoon system of Florida. Proc. Biol. Soc. Wash. 108 (4): 643-648.

Mantelatto, F.L.M. \& L.L. Dias. 1999. Extension of the known distribution of Charybdis hellerii (A. Milne Edwards, 1867) (Decapoda, Portunidae) along the western tropical south Atlantic. Crustaceana 72 (6): 617-620.

Negreiros-Frınsozo, M.L. 1996. The zoea I of Charybdis hellerii (A. Milne Edwards, 1867) (Decapoda, Portunidae) obtained in laboratory. Nauplius, Rio Grande, 4: 165-168.

POR, F.D. 1978. Lessepsian migration. The influx of the Red Sea biota into the Mediterranean by way of the Suez Canal. Ecol. Stud. 23: 1-238.

Tavares, M. \& J.B. de MendonçA JR. 1996. Charybdis hellerii (A. Milne Edwards, 1867) (Brachyura: Portunidae), eighth nonindigenous marine decapod recorded from Brazil. Crustacean Res. 25: 151-157.

Recebido em 23.XI.2000; aceito em 02.VII.2001.

Revta bras. Zool. 18 (Supl. 1): 357 - 358, 2001 